\title{
Accounting Conservatism in Stock Price Downfall Risk in "Tehran Stock Exchange"
}

\author{
Sahar Taremi ${ }^{1}$, Bamdad Partovi \\ Received: 20.08.2015 \\ Revised: 25.09 .2015 \\ Accepted: 30.11.2015
}

\begin{abstract}
As the economic departments' managers tend to report good news, they simultaneously try to conceal bad news. Conservatism procedures not only resist against these tendencies of management, but also they decrease the investment risk in stock. In this research, the relationship between accounting conservatism and the risk related to downfall of stock value has been studied using historical data about 29 car and pieces companies accepted in Tehran Stock Exchange during the years 2010- 2012. The results obtained from performing the logistic regression model show that there is a negative and significant relationship between the risk of stock value decline and the level of conservatism for case-study statistic sample companies. In other words, during the research period, those companies in which the more conservative procedures have been applied in financial reporting, they have less encountered the risk of stock value decline. In the present research, company size was involved as a controlling variable in hypothesis test pattern that a significant relationship wasn't observed between this variable and the research's dependent variable.
\end{abstract}

Keywords: accounting conservatism, risk, the risk of stock value downfall, company size, accounting procedures

\section{Introduction}

Production centers, services, companies, production agencies, various official services or intermediate, insurance, and counseling services as well as different manufacturing companies and goods and services production from each kind or group need to control or account the prices and profits; in other words, they especially need to compute the prices' income and the interest resulting from production and service after different daily, monthly, or annual payments that is called "accounting". Today, the advanced accounting has been changed along with production evolutions and expectations and suppliants' expectancies, and it is computed by new methods, modern electronic instruments, working operations, and different codes that they are appropriate for time and place conditions of economic culture in different societies. Moreover, if the production companies and agencies and factories besides modern productions and technologies and complicated banking methods apply the traditional and pastorientated accountings with easy access to exchange, money, and demand, the possibility of risk and abusing or fraud will increase and idiomatically its conservatism will increase. Conservatism is a disciplinarian mechanism that restrains managers' profiteering motives, and it decreases the managers' power for accelerating

\footnotetext{
Author's Address

${ }^{1}$ Department of management, Islamic Azad University, Abhar Branch, Abhar, Iran.

${ }^{2}$ Islamic Azad University of Abhar, Abhar Branch, Abhar, Iran.
}

good news' report and delaying bad news'propagation. In other words, conservatism in accounting not only limits the managers' ability to report good news quickly as these nonconfirmatory news (with interest entity) cannot be distinguished under the influence of conservative accounting procedure, but also it increases the possibility of recognizing bed news through using more weak levels of confirmatory standard that they cannot be approved by loss entity (Chen, et al, 2001). According to abovementioned approach, it is expected that the more conservative a company's accounting methods, the less the possibility of concealing bad news related to that company. In this case, it is predicted that the more conservative companies will experience the crisis resulting from sudden accumulated bad news less than other companies. In this research, following the study of car and pieces companies accepted in Tehran Stock Exchange we try to investigate its relationship with the risk of stock value downfall in terms of accounting conservatism in these companies.

\section{The concept of conservatism:}

Conservatism has traditionally been stated based on the proverb known as "Don't identify any interest, but identify all the losses." (Rezazade \& Azad cited Bliss, 1924). Despite the lack of comprehensive definition given for conservatism, two important features of conservatism have been studied in accounting literature. They are as follows: 
1. First, existence of support for representing book value towards its market value less than its real amount that it is introduced by Ohlson (1995).

2. Second, tendency towards the acceleration in order to identify the losses and delay the interests' identification that it is stated by Basu (1997). Vatez explained that different confirmatory conservatism is needed for identifying the interests against the losses.

Basu (1997) has defined the conservatism as an accounting tendency towards the necessity for higher level of verifiability in order to recognize good news rather than the level of required verifiability for identifying bad news that it results in underestimating the interests and especially the assets. Iran audit organization's technical committee (2007) explains that financial statements' providers experience the ambiguities shading inevitably on most of events and conditions. Typical examples of these ambiguities include accessibility of demands, possible useful age of fixed assets, and the number or level of claims related to warranty of sold commodity. Such instances are investigated by observing the caution in financial statements besides the exposure of their entity and level. "Caution is the application of some level of observation required for applying the judgment for accounting measures in ambiguous circumstances so that incomes and assets aren't overestimated, and prices or debts aren't underestimated."

\section{Effective factors on conservatism}

Various researches have investigated the factors about existence of conservatism in financial reports. As it was mentioned before, Vatez (2003) summarizes these factors in four models including the presence of different contracts between business unit and external stakeholders, the possibility of legal claims' design against the business unit, decreasing or delaying the payable tax, and neutralizing the managers' predilection for representing the exaggerated reports. Zimerman (1983) and Kordler \& Shahriyari (2009) have stated that while trying to decrease the political costs, the larger companies act more conservative for representing the financial reports. In contrast, Eterdiz (2011) explains that as the agency problem in new-established and small companies is in higher level, the conservatism in this kind of companies is more than the larger companies. The findings about Erasmous' research committee (2010) indicate that the higher level of leverage and consequently the more conflict between creditors and shareholders, especially in profit sharing policies' department is another factor about the adoption of conservative approach.

\section{The concept of risk}

Different interpretations have been created in various aspects for the word called "risk" in terms of its applications, and authors have represented different definitions about this term. At the outset, it seems that the word known as "risk" comes out the clear concept in the mind. When it is said that there is risk in a special action or situation, the hearer finds that there is an uncertainty related to results obtained from that action, and it may be said that at least one of the possible results will be undesirable. In other words, by using this word, the speaker has implicitly referred to uncertainty and unpredictability of future results; for this reason when we have more ability about future prediction, there is less risk against us. In contrast, the less our ability about future prediction, the more the risk against us will exist. Understanding the concept of risk as above can be useful due to full transition of speaker's purpose to hearer in daily conversations. Also, we have based this meaning, and we try to get a comprehensive and more precise definition of risk by its expansion (Mazloomi, 2010, p3).

\section{History of research}

* Ma, T (2011) performed his research about U.S companies during the years 1987-2007, and the results obtained from this research show that there is a negative relationship between conservatism and corporate investment and future operational condition for companies in which there are financially contractual restrictions. The obtained results are based on prediction of conservative literature, and according to this prediction, the conservatism can cause not to be accepted some projects with net positive but little present value by managers.

*Biddle et al (2012) have studied the effects of accounting conservatism on investment incentives by managers, and the results obtained from this research indicate the negative relationship between company's conservatism and its investment and future operational performance for companies encountering the financial limitations. This negative correlation between investment and conservatism can be 
justified by using the literature, this means that conservatism can create the unhealthy incentives for investment by managers; consequently the managers won't accept the projects with positive net present value.

*Foroughi \& Mirzaie (2012) have studied the relationship between conditional conservatism in financial reporting and the risk related to future downfall of stock price, and their selective sample was stock companies chosen during the years 2001- 2009. The results obtained from this research show that there is the inverse relationship between conditional conservatism and the risk related to future downfall of stock price; in addition the results suggested that when there is information asymmetry between managers and investors, the ability of conditional conservatism is more for decreasing the risk related to next downfall of stock price.

*Moshki \& Fattahi (2011) have examined the relationship between accounting conservatism and the risk of stock price downfall by using the historical data related to 116 companies accepted in Tehran Stock Exchange during the years 20062010. The results suggest the existence of negative and significant relationship between the periods of stock price downfall and the level of conservatism for the companies included in casestudy statistical sample. In other words, during the research period, some companies in which the more conservative procedures have been used in their financial reporting, they have less encountered the risk of decreasing stock price.

* It cannot be deduced that there is a negative and significant relationship between the size of company and its conservatism.

6.Conclusion and summary of studies and representing the research's conceptual model

Most of the researchers like Chen et al (2011) believe that a company's stock price's changes results from internal information management. When the information have accidentally entered to the market, and the process of information propagation is systematically done whether it is good or bad; thus it can be said that the reported information have symmetric distribution. It means that if managers reveal all information quickly, this action causes the distribution of stock returns to be symmetric, i.e. the average of positive return volume about good news must be equal to the average of negative return volume related to bed news (Kootari et al, 2009).

However, the managers always tend to conceal the negative information and news from investors, and they want to accumulate this news within the company. For example, by considering one period's costs as asset, they cause the costs to be decreased and more interests in financial statements to be reported. The results obtained from these operations lead to appear the business department image better than its real situation; as a result motivation of individuals outside the organization increases, and they tend to invest in business unit (Ball, 2009).

In case the managers can prevent from revealing bad news for a long time, this news is accumulated inside the company. On the other hand, the amount of bad news that managers can accumulate is limited, since when the amount of accumulated bad news reaches to certain threshold, it is impossible and costly to keep them for a long time, and the lack of their disclosure is difficult. Consequently, the mass of undesirable news is suddenly entered into the market after reaching to its peak, and it results in sharp drop of stock market or stock price downfall (Hootoon et al, 2009).

In this research, the following conceptual model is represented in the graph by studying the previous researches at home and abroad in which there are three variables known as independent, dependent, and controlling variables. To measure the conservatism index of case-study companies, the model represented by "Giouli et al (2007)" has been used, and the given model by "Hotoon et al (2009)" is used for measuring the level of risk related to stock price drop. Moreover, evaluating the controlling variable is performed by natural logarithm related to assets of the surveyed companies like in research represented by "Moshki \& Fattahi (2011)".

At last, the research conceptual model is given as follows: 


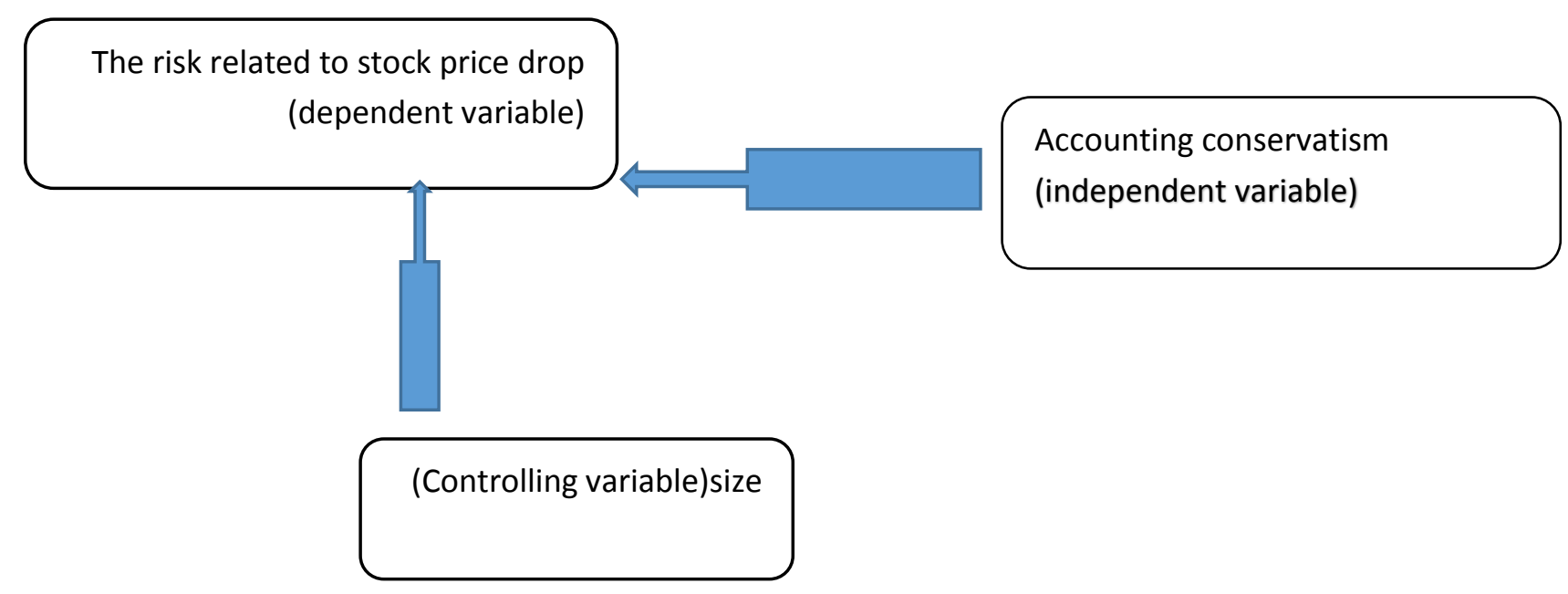

\section{Research method}

This research is a kind of post-event descriptive and correlation research in which we try to describe the relationships between variables using statistic tests; moreover it is a kind of applied research from the aim viewpoint. An applied research tries to reply to a practical problem existing in a real world (Khaki, 2004, p94).

\subsection{Data collection methods}

Library method has been used in order to collect data; so some of the actions are represented in this case:

1. Studying the books related to research variables

2. Experts' ideas in the form of books, journals, articles, and other performed researches associated with this subject

3. Compiling the research theoretical foundations by the present theses

4. Regarding the amendments related to the variables, required data has been gathered from audited financial statements and studied companies' attached notes via the site known as management of development research and Islamic studies (www.rdis.ir), codal site (www.codal.com), official website of studied companies, exchange notices company website, and other official websites in Tehran Stock Exchange as well as information banks including Modern RAHAVARD software.

\subsection{Statistical method of data analysis}

Descriptive statistics (such as distribution of data frequency, mean, and standard deviation, ...) and graph have been used for data analysis, and multiple linear regression is applied for computing the research dependent variable that is the risk related to stock price downfall. Finally, the logistic regression's statistical technique has been used for testing the research hypothesis.

\subsection{Research}

variables

Table: Research variables

\begin{tabular}{|l|l|}
\hline Research variables & Description \\
\hline 1. Independent variable & $*$ Accounting conservatism \\
\hline 2. Dependent variable & *The risk of stock price drop \\
\hline 3. Controlling variable & *Size \\
\hline
\end{tabular}

\subsection{Research hypotheses}

In this research, there is main hypothesis and two secondary hypotheses as follows:

The main hypothesis: There is a relationship between the conservatism variables in financial reporting or the size of company and the risk related to stock price drop for auto parts companies accepted in Tehran Stock Exchange.
The first secondary hypothesis: There is a relationship between conservatism variable in financial reporting and the risk of stock price downfall.

The next secondary hypothesis: There is a relationship between the size of company and the risk of stock price drop. 
7.5.Descriptive statistics analysis of research variables
Following table shows the results of analysis for research variables.

Table: Results of research variables analysis

\begin{tabular}{|l|l|l|l|l|}
\hline Description & $\begin{array}{l}\text { The level of } \\
\text { conservatism } \\
\text { given by Giooli et } \\
\text { al (2007) }\end{array}$ & Size & $\begin{array}{l}\text { Index represented } \\
\text { by Hotoon et al } \\
(2009)\end{array}$ & output \\
\hline Frequency & 40 & 40 & 40 & 40 \\
\hline Average & -0.0944 & 13.861 & 0.287 & 0.951 \\
\hline Mean & -0.055 & 13.48 & 0.259 & -0.503 \\
\hline $\begin{array}{l}\text { Standard } \\
\text { deviation }\end{array}$ & 0.122 & 1.868 & 0.131 & 9.462 \\
\hline
\end{tabular}

As the results indicate, according to the data, the most standard deviation is related to the output variable indicating the distribution of this variable's data.

\section{Research hypotheses test}

\subsection{Main hypothesis test}

Null hypothesis (H0): There isn't any relationship between conservatism variables in financial reporting or the size of company and the risk of stock price downfall for auto-parts companies accepted in Tehran Stock Exchange.

First hypothesis (H1): There is a relationship between conservatism variables in financial reporting or the size of company and the risk of stock price downfall for auto-parts companies accepted in Tehran Stock Exchange.

Logistic regression model has been used for testing above hypothesis. In this research, number 1 is given to the periods related to stock price downfall, and number zero (0) indicates the periods for stock price rising. Therefore, regarding accounting conservatism's variables and the other parameter called size as well as its effect on risk related to stock price downfall, this test is performed in sample companies in this research. The results obtained from this test are represented as follows:

The first results is called Omnibous table.

\subsection{Omnibous table:}

\begin{tabular}{|l|l|l|l|l|}
\hline Significance level & $\begin{array}{l}\text { The level of } \\
\text { freedom }\end{array}$ & $\begin{array}{l}\text { Chi-square } \\
\text { statistic }\end{array}$ & & \\
\hline $\mathbf{. 0 3 2}$ & 2 & $\mathbf{2 5 . 4 2 7}$ & Step & Step 1 \\
\hline .032 & 2 & 25.427 & Block & \\
\hline .032 & 2 & 25.427 & Model & \\
\hline
\end{tabular}

Chi-square statistic shows that whether independent variable or variables affect dependant variable or not. At the first step, the Chi-square statistic is 25.427 and its significance level equals 0.032 , and it is less than 0.05 ; thus independent variables affect the dependent variable, and it shows the proper fitness. This effect is significant in $95 \%$ confidence level. In fact, this result indicates the confirmation of the research's first hypothesis. In other words, "there is a significant relationship between conservatism variables in financial reporting or the size variable and the risk of stock price downfall in automotive and pieces companies accepted in Tehran Stock Exchange"

8.3.The first secondary hypothesis test:

This hypothesis is as follows:

*H0: There isn't any relationship between conservatism variable in financial reporting and the risk of stock price downfall.

${ }^{*} \mathrm{H} 1$ : There is a relationship between conservatism variable in financial reporting and the risk of stock price downfall.

Table: the result of independency test of the first secondary hypothesis

\begin{tabular}{|l|l|l|l|}
\hline Significance level & df & Value & \\
\hline 0.033 & 85 & $184 / 876$ & Pearson Chi-Square \\
\hline
\end{tabular}


The resulting number for Chi-square test is 184.876, and its significance level equals 0.033. As the obtained number for significance level is less than 0.05 , the first hypothesis is confirmed. In other words, "there is a significant relationship between conservatism variable in financial reporting and the risk related to stock price downfall".

\subsection{The next secondary hypothesis test:}

*HO: There isn't any relationship between the size variable and the risk of stock price downfall.

${ }^{*} \mathrm{H} 1$ : There is a significant relationship between size and the risk of stock price drop.

8.5.The result of dependency test of second secondary hypothesis

\begin{tabular}{|l|l|l|l|}
\hline Significance level & df & Value & \\
\hline 0.590 & 77 & 73.550 & Pearson Chi-Square \\
\hline
\end{tabular}

Regarding the obtained results and the amount of significance level that is more than 0.05 , it can be concluded that "there isn't any relationship between the size and the risk of stock price downfall". That is, this second secondary hypothesis is rejected.

8.6.The summary of results obtained from the research hypotheses test

Table: the summary of the research main hypotheses test's results

\begin{tabular}{|l|l|l|l|l|l|}
\hline Row & $\begin{array}{l}\text { Summary of } \\
\text { hypothesis thesult }\end{array}$ & $\begin{array}{l}\text { The kind of } \\
\text { test }\end{array}$ & $\begin{array}{l}\text { Important } \\
\text { statistics }\end{array}$ & result \\
\hline 1 & $\begin{array}{l}\text { Testing the } \\
\text { relationship } \\
\text { between } \\
\text { conservatism } \\
\text { and size } \\
\text { variables with } \\
\text { the risk of } \\
\text { stock price } \\
\text { downfals } \\
\text { statistic= } \\
14 / 211 \\
\mathrm{R}^{2}=0.282\end{array}$ & $\begin{array}{l}\text { Hypothesis } \\
\text { confirmation }\end{array}$ & \\
\hline 2 & $\begin{array}{l}\text { Testing the } \\
\text { relationship } \\
\text { between } \\
\text { conservatism } \\
\text { and the risk of } \\
\text { stock price } \\
\text { drop }\end{array}$ & $\begin{array}{l}\text { Chi-Square } \\
\text { test }\end{array}$ & 0.032 & $\mathrm{X}^{2}=184 / 876$ & $\begin{array}{l}\text { Hypothesis } \\
\text { confirmation }\end{array}$ \\
\hline 3 & $\begin{array}{l}\text { Testing the } \\
\text { relationship } \\
\text { between size } \\
\text { and the risk of } \\
\text { stock price } \\
\text { downfall }\end{array}$ & $\begin{array}{l}\text { Chi-Square } \\
\text { test }\end{array}$ & 0.59 & $\mathrm{X}^{2}=73 / 55$ & $\begin{array}{l}\text { Hypothesis } \\
\text { rejection }\end{array}$ \\
\hline
\end{tabular}

9.Practical suggestions by researcher for research results' users

Existing the confidential information in companies and the lack of public access to this information causes the information asymmetry to be created that is a king of social injustice, and it results in creating a difference in suggested prices for sales. It seems that managers as custodians of presentation and disclosure of information play an important role in establishing information asymmetry in company and market levels. Economical agencies' managers tend to show the company's condition in a desirable way; so this action with regard to their profit-seeking motivations can be exactly investigated. The principle of conservatism can hinder these managers' profit-seeking motivations, and it can keep the rights of minority shareholders.

The results obtained from logistic regression test show the presence of a significant reverse relationship between conservatism and the risk of 
stock price downfall. This finding corresponds with the results obtained from Botosan (2006), Kotari et al (2009) and Kim and Jhang (2012) researches that they were performed during the years 1964- 2007; moreover this finding completes the researches performed by LaFond and Watts(2008) indicating the effect of conservatism on decline of information asymmetry. The present research's findings also correspond to the results obtained from Sujis (2008), Ryan (2006) and Francis et al (2005) studies, these researches indicate that in profit management process, managers try to collect bad news inside the company, and they try not to reveal them. When this accumulated negative news reaches to its peak, they at once enter to the market resulting in the decline of stock price. In this case, it can be understood that conservative procedures can resist against the management motivations towards concealing bad news.

Regarding the obtained results, it can be suggested that:

* Based on the results obtained from research findings, the preparation and compilation's players of theoretical bases of financial reporting and national accounting standards are recommended that consider this research and other similar internal researches' results. They also are recommended to determine the position of theoretical bases and special qualitative features of financial reporting such as conservatism with regard to accounting procedures and present conditions in country's capital market.

*Conservatism is an affective mechanism to restrain the managers' profit-seeking motivations, and it seems that it can be useful in protecting the rights of all shareholders. Therefore, the selected accounting procedures by management for providing the financial statements and necessity of national accounting standards based on conservative reporting can play a major role in order to adjust the risk of stock price drop.

*It appears that drafting committee of accounting standards tries to omit the conservatism from new conceptual framework, and it tries not to consider the concepts such as fair value and neutral accounting. However, the results obtained from the main hypothesis test show that the existence of conservatism in financial reporting decreases the risk of stock price downfall. Therefore, it is suggested that editing references of accounting standards act more cautiously towards the deletion of the principle of conservatism from the conceptual framework.

*Investors and analysts are recommended that they must consider the accounting methods of automotive and pieces companies when deciding about short-term or long-term investments besides using the presented statistics in financial reporting such as taking the conservative or aggressive practices for producing the mentioned statistics.

\section{0.researcher's recommendations for future researches}

Following subjects are suggested in order to perform the future researches in relation to this research:

1. Designing, identifying, and presenting a model about measuring the accounting conservatism and its test for companies accepted in Tehran Stock Exchange

2. Performing the present research in statistical universe of all the companies accepted in Tehran Stock Exchange

3. Studying the relationship between company's growth opportunities and occurrence or nonoccurrence of event of the risk related to stock price downfall

\section{Research limitations}

Moving forward in order to reach the goal always accompanies with some limitations that causes the considered goal to be achieved slowly and with more difficulty. Research as a process for achieving the aim of research problem solving is not excluded from this fact. Therefore, in this section by representing the research limitations, we are trying to deliver this message to reader in order to be able to act with more awareness about generalizing the research results and to judge about research process fairly. In this regard, the present research limitations can be mentioned as follows:

1. Time domain of the present research has been gathered between the years 2010-2012; therefore it can be noticed that this research's results cannot be generalized before the year 2010 .

2. Extracted data from companies' financial statements was not adjusted in terms of inflation. If the mentioned information is adjusted, different results can be obtained.

3. If all the companies accepted in Stock Exchange are determined as a universal statistical, the results will change completely. 


\section{References}

Ohlson, J, 1995. Earnings, Book Values, and Dividends in Security Valuation. Contemporary Accounting Research (Spring): 661-688.

Basu, S. 1997. "The conservatism principle and the asymmetric timeliness of earnings", Journal of Accounting and Economics, vol.24, pp. 3-37.

LaFond, R., \& Watts, R. 2008. "The information role of conservatism". The Accounting Review, vol. 83, pp. $443-478$.

Kim, J.B., and Zhang, L., 2012. Accounting Conservatism and Stock Price Crash Risk: FirmLevel Evidence. Unpublished Paper. Available http://papers.ssrn.com/sol3/papers.cfm?abstract_id=152 $\underline{1345}$
Biddle, G. Ma, M. and Wu, F. 2012. "Conditional Conservatism and the Cost of Equity Capital: Informational, Fundamental, and Behavioral Effects", working paper, University of Hong Kong.

Botosan, C.A. 2006. "Disclosure and the cost of capital: what do we know?", Accounting and Business Research, vol. 36 (Special Issue), pp. 31-40

Ryan, S.G. 2006. "Identifying conditional conservatism", European Accounting Review, vol.15, pp. 511-525.

Suijs, J. 2008. "On the value relevance of asymmetric financial reporting policies", Journal of Accounting Research, vol.46, pp. 1297-1321

Francis, J., LaFond, R., Olsson, P. and Schipper, K. 2005. "The market pricing of accruals quality", Journal of Accounting and Economics, vol. 39, pp. 295-327. 